\title{
Mesothelial Cells Count
}

National Cancer Institute

\section{Source}

National Cancer Institute. Mesothelial Cells Count. NCI Thesaurus. Code C147398.

The determination of the amount of mesothelial cells present in a sample. 